\author{
Kalaman 0. \\ Ph.D., Associate Professor \\ E-mail: kalaman.olga@gmail.com \\ Zborshik D. \\ Undergraduate \\ Department of Management and Logistics \\ Odessa National Academy of Food Technologies \\ Kanatna str., 112, Odesa, Ukraine, 65039 \\ E-mail: dasha.zborshik@mail.ru
}

\title{
THE ANALYSIS OF VITICULTURE AND WINEMAKING PROBLEMS IN UKRAINE MANAGEMENT OF THE INDUSTRY DEVELOPMENT
}

The article analyzes the condition, the development dynamics and the main problems of the viticulture and winemaking industry in Ukraine and in the world. The particular attention is paid to the causes of the emerging situation in the industry and the ways to overcome them. The basic mechanisms that should be used to solve all problems of the industry have been revealed. The advanced innovative directions have been suggested, which will help to improve the industry condition and to return it the status as one of the most effective branches of agro industrial complex of Ukraine. enterprises.

Key words: gross grape harvest, grape parcel area, grape processing, wine production, winemaking

This work is licensed under a Creative Commons Attribution 4.0 International License http://creativecommons.org/licenses/by/4.0/

Statement of the problem and its connection with important scientific and practical tasks. Viticulture and winemaking in Ukraine have always been important types of economic activity. Ukraine integration into the WTO, unbalanced state policy in this field have led to the wine industry inability to work effectively in a harsh competitive environment. The situation in the industry requires careful analysis and development of suggestions for its improvement.

The analysis of the latest publications on the problem. In Ukraine, a number of domestic scientists were engaged in the research of the state of problems of winemaking, among them: Avidzba A.M., Buzni A.N., Gorkusha O. M., Marmul L.O., Matchina I.G., Ribintsev V.A., Sabluk P.T., Cherven I.I. etc., but the problems of the current state of the industry require constant analysis.

Forming of the aims of the research. Dynamic changes in the country economic situation indicate the need for a constant study of the industry situation and the factors that led to it. It is therefore advisable to analyze the problems of viticulture and winemaking and explore the management of the industry's development mechanism.

Giving an account of the main results and their substantiation. By 2016, the total area of vineyards in the world was almost 18,000 acres. Of these, more than half of them are in Europe. The second place is occupied by Asian countries, due to steady increase in the number of vineyards in China, India and Iran [1].

Today, viticulture is spread throughout the world, but the major arrays for the cultivation of technical varieties are concentrated between $30-50^{\circ}$ north latitude and $30-40^{\circ}$ south latitude. This location is primarily due to the agro-climatic factors, features of the relief and soil cover.

In the mid-80s of the last century, massive deforestation of vineyards in the Crimea and in the south of Ukraine was carried out during the anti-alcohol campaign. In the nineties, due to the total shortage of funds and the destruction of economic ties, the restoration of vineyards in Ukraine wasn't practically carried out. Today, most of the vineyards are outdated and are in an unproductive age. The area of vine grape plantations in the world grows year by year, compared with 2011 an increase of 2,9\% was observed in 2016, however, the area of vine grape plantations in Ukraine declined by $38,2 \%$ [2] .

The areas occupied by vineyards on the territory of Ukraine do not fully characterize the volume of the actual yield. After all, the yield of grapes depends on the agro-climatic conditions, the level of fertilizer use, the culture of agriculture, and other factors. According to experts, the landing of one hectare costs 8-15 thousand dollars. The first crop from the planted area can be obtained in 4-5 years. Despite this, there are imports of grape seedlings into Ukraine, which indicates that Ukrainian companies are working on the restoration of vineyards. Mostly red varieties of grapes are planted, as there is traditionally a high demand for red wines in the CIS countries, including Ukraine. However, experts are inclined to think that the future will belong to Ukraine`s own raw material base [3]. 
Viticulture in Ukraine has recently undergone significant changes. After the annexation of the Crimea, the share of production in the households has grown significantly, which was 7,9\% in 2017 against in 2016. The vineyard area in fecundity has sharply decreased from 67,7 thousand hectares respectively in 2010 to 42,7 thousand hectares in 2016, especially in agricultural enterprises - by 42.5 and $41.9 \%$ against 2010 and 2016, respectively. On the other hand, the yield of grapes, which had always been twice as high in households, grew by $15 \%$ compared to 2016 , and against 2010 by $63.7 \%$. At the expense of productivity, the decline in production volumes after the annexation of the Crimea was significantly lower than the decrease in planting in the fruiting age by $24.3 \%$ compared to 2016 (area - by $34.4 \%$ ), while in households the gross grape harvest even increased by $1,8 \%$ while the area of vineyards decreased by $3,1 \%$ $[4,5]$.

The gross grape harvest in 2016 was $97,8 \%$ of the 2015 level, which was $88,8 \%$ of the 2014 level (table $1)$.

Gross harvest of grapes in Ukraine*

Table 1

\begin{tabular}{|c|c|c|c|c|}
\hline Year & $\begin{array}{c}\text { Vineyard area, } \\
\text { ths. ha }\end{array}$ & Yield, ton / ha & $\begin{array}{c}\text { Gross harvest of grapes, } \\
\text { ths. tons }\end{array}$ & $\begin{array}{c}\text { The ratio of the gross collection of } \\
\text { grapes to the previous year, } \%\end{array}$ \\
\hline 1990 & 143,3 & 5,83 & 835,7 & - \\
\hline 1995 & 137,7 & 3,32 & 457,3 & 54,72 \\
\hline 2000 & 99,4 & 5,17 & 513,8 & 112,36 \\
\hline 2001 & 105 & 3,54 & 336,0 & 106,40 \\
\hline 2002 & 103 & 3,94 & 359,0 & 140,67 \\
\hline 2003 & 99 & 5,90 & 505,0 & 74,06 \\
\hline 2004 & 82,8 & 4,52 & 374,0 & 118,34 \\
\hline 2005 & 80,6 & 5,49 & 442,6 & 67,98 \\
\hline 2006 & 75,8 & 3,97 & 300,9 & 119,54 \\
\hline 2007 & 71,2 & 5,05 & 359,7 & 115,46 \\
\hline 2008 & 70,9 & 5,86 & 415,3 & 112,86 \\
\hline 2009 & 71,0 & 6,60 & 468,7 & 87,03 \\
\hline 2010 & 67,6 & 6,03 & 407,9 & 127,95 \\
\hline 2011 & 69,1 & 7,55 & 521,9 & 87,37 \\
\hline 2012 & 67,1 & 6,72 & 456,0 & 126,18 \\
\hline 2013 & 44,2 & 8,58 & 575,4 & 75,70 \\
\hline 2014 & 44,2 & 9,86 & 435,6 & 88,68 \\
\hline 2015 & 41,8 & 9,23 & 386,3 & 97,80 \\
\hline 2016 & 42,7 & 8,84 & 377,8 & \\
\hline
\end{tabular}

* compiled by the authors on the basis of the sources [4,5]

Also, since 2013 slight improvements have been noted in the vineyard: the yield in 2016 reached the level of 8,84 tons/ha (taking into account the regulatory level of expenditure, grape production is effective at the yield of not less than 5 tons/ha), the gross harvest of grapes has decreased and amounted to 377.8 thousand tons, the area of vineyards significantly decreased. Interestingly, in Europe, the yield is more than 10 tons per hectare, while the potential of some plantings can reach 35-40 tons per hectare. The dynamics of the development of viticulture and winemaking in Ukraine is as follows.

In 2010 , the area of grape plantations in agricul- tural enterprises of Ukraine amounted to 87 thousand hectares and decreased year by year and amounted to 75 thousand hectares in 2014, 49 thousand hectares in 2015, and 41.5 thousand hectares in 2016. At the same time, the productivity dynamics of 1990-2016 in agricultural enterprises of Ukraine increased from $5.83 \mathrm{t} /$ ha in 1990 to $8,84 \mathrm{t} /$ ha in 2016. Consequently, the dynamics of the processing of grapes to wine grown as well as purchased ones (table 2) indicates a decline in the processing of grapes from 2014. As seen from the data of the dynamics of grape yield during the reporting period, they indicate an increase in the yield.

Table 2

Volume of processing of grapes on wine materials by region*

\begin{tabular}{|l|c|c|c|c|c|c|c|}
\hline \multirow{2}{*}{\multicolumn{1}{|c|}{ Region name }} & \multicolumn{7}{|c|}{ YEARS } \\
\cline { 2 - 8 } & 2010 & 2011 & 2012 & 2013 & 2014 & 2015 & 2016 \\
\hline Zakarpats'ka & 7815,8 & 6512,5 & 9469 & 29668,2 & 8199,6 & 6757,8 & 4915,5 \\
\hline Mykolayivs'ka & 82456,6 & 58748,7 & 53928 & 71207,5 & 44674,7 & 44365,7 & 101772,5 \\
\hline Odes'ka & 191541,1 & 131427,5 & 146452,5 & 185533,3 & 139921,9 & 114134,7 & 121448,8 \\
\hline Khersons'ka & 26403,8 & 47061,1 & 29663,6 & 41710,6 & 36136,9 & 28770,4 & 25719,5 \\
\hline Crimea & 90681,5 & 86332,8 & 73151,6 & 97244,6 & $\ldots 1$ & $\ldots 1$ & $\ldots 1$ \\
\hline Total for Ukraine & 417689 & 353900,8 & 329629,7 & 425364,2 & 228933,1 & 194028,6 & 253856,3 \\
\hline
\end{tabular}

1 - Not including the temporarily occupied territory of the AR of Crimea and the city of Sevastopol.

* compiled by the authors on the basis of the sources $[5,6,7,8]$ 
According to the official data, around two hundred Ukrainian enterprises are involved in the processing of grapes, the production of wine, champagne wines and cognac in the winemaking industry. Among them we can clearly distinguish two large groups: traditional enterprises with their own vineyards, and companies of a new wave, dealing exclusively with bottling of wine. The volume of processing of vines and grown grapes to wine materials in 2016 decreased by $7.71 \%$ in comparison with 2015, in Mykolaiv - by $20.78 \%$, in Kherson by $40.1 \%$, but in Odessa - increased by $3.25 \%$ (table 3 ).

Table 3

Volume of processing of vinegrown grapes to wine materials by region*

\begin{tabular}{|l|c|c|c|c|c|c|c|}
\hline \multirow{2}{*}{\multicolumn{1}{|c|}{ Region name }} & \multicolumn{7}{c|}{ YEARS } \\
\cline { 2 - 8 } & 2010 & 2011 & 2012 & 2013 & 2014 & 2015 & 2016 \\
\hline Zakarpats'ka & 644,9 & 407,9 & 1075,3 & $\ldots 2$ & $\ldots 2$ & $\ldots 2$ & $\ldots 2$ \\
\hline Mykolayivs'ka & 4647,7 & 10202,6 & 4105,8 & 8643,0 & 4767,1 & 3776,5 & 6473,0 \\
\hline Odes'ka & 26486,4 & 29486,6 & 32816,3 & 41301,6 & 26848,3 & 27722,1 & 28447,1 \\
\hline Khersons'ka & 5034,2 & 12604,9 & 6894,6 & 9656,0 & 7457,7 & 4467,9 & $\ldots 2$ \\
\hline Crimea & 38965,2 & 46432,0 & 32901,7 & 36305,0 & $\ldots 1$ & $\ldots 1$ & $\ldots 1$ \\
\hline Total for Ukraine & 92044,8 & 119609,4 & 92245,5 & 113677,2 & 39176,6 & 36157,3 & 42469,7 \\
\hline
\end{tabular}

1- Not including the temporarily occupied territory of the AR of Crimea and the city of Sevastopol.

2- Data is deleted in order to ensure compliance with the requirements of the Law of Ukraine "On State Statistics" regarding the confidentiality of information.

* compiled by the authors on the basis of the sources $[5,7,8]$

The processing volume of the purchased grapes to wine materials in 2016 compared to 2015 as a whole increased by $17,5 \%$, in Mykolaiv - increased by $71,4 \%$, in Odessa - by $2.6 \%$ (table 4 ).

Table 4

Volume of processing of the purchased grapes to wine materials by region*

\begin{tabular}{|l|c|c|c|c|c|c|c|}
\hline \multirow{2}{*}{\multicolumn{1}{c|}{ Region name }} & \multicolumn{7}{c|}{ YEARS } \\
\cline { 2 - 8 } & 2010 & 2011 & 2012 & 2013 & 2014 & 2015 & 2016 \\
\hline Zakarpats'ka & 7170,9 & 61104,6 & 8393,7 & $\ldots 2$ & $\ldots .2$ & $\ldots 2$ & $\ldots .2$ \\
\hline Mykolayivs'ka & 77808,9 & 48546,1 & 49822,2 & 62564,5 & 39907,6 & 40589,2 & 95299,5 \\
\hline Odes'ka & 165054,7 & 101940,9 & 113636,2 & 144231,7 & 113073,6 & 86412,6 & 93001,7 \\
\hline Khersons'ka & 21369,6 & 34456,2 & 22769,0 & 32054,6 & 28645,6 & 24302,5 & $\ldots .2$ \\
\hline Crimea & 38269,3 & 39608,9 & 40249,9 & 60939,6 & $\ldots 1$ & $\ldots 1$ & $\ldots 1$ \\
\hline Total for Ukraine & 309917,8 & 230898,4 & 235130,8 & 308736,3 & 189722,9 & 157871,3 & 211386,6 \\
\hline
\end{tabular}

1 - Not including the temporarily occupied territory of the AR of Crimea and the city of Sevastopol.

2 - Data is deleted in order to ensure compliance with the requirements of the Law of Ukraine "On State Statistics" regarding the confidentiality of information.

* compiled by the authors on the basis of the sources $[5,8]$

In the wine industry, the production of grapes is concentrated in large farms with more than 500 hectares of vineyards. In 201532 such farms produced almost $60 \%$ of all grapes. Without the Crimea, the share of such farms has changed insignificantly and amounted to $57.1 \%$. It is the large farms with an average vineyard area of 797 hectares that have the best indices: in 2015 their yield was $101 \mathrm{c} /$ ha against $86 \mathrm{c} /$ ha for all agricultural enterprises, the profit per 1 hectare of vineyards - 14.7 thousand UAH (8.8 thousand UAH), the level of profitability of grape production - $136 \%(80 \%)$ [9].

The processing of grapes to the wine material by grade is presented in table 5, where the decline in the processing of grapes varieties in 2016 compared to 2015 , namely Aligote by $20 \%$, Cabernet Sauvignon by $16 \%$, Merlot by $42.44 \%$, Muscat (white, pink, etc.) by $35.7 \%$, Odesa Black by $30.5 \%$, Pinot (white, black, gray) by $12.3 \%$, Riesling by $11 \%$, Rkatsiteli by $21.45 \%$, Saperavi Northern by $1.53 \%$, Sauvignon by $33.8 \%$, Fetyaska by
$18 \%$, Chardonnay by $51 \%$ other varieties by $3.6 \%$. Growth showed Bastardo Magaratsky's grape variety at $51 \%$. Aligote and Chardonnay remain the most common types of grapes for processing in 2016 respectively 12 and $10 \%$ and Cabernet Sauvignon $9 \%$ in the total amount of the processed grapes.

The such varieties of grapes, as aligote, chardone, white musk, Cabernet Sauvignon have mostly been processed to wine material in comparison to other varieties. Such varieties of grapes as chardone, rysling, foam (white, black, gray) have shown significant growth for the last 3 years.

Ukraine produces $10.1 \mathrm{~kg}$ of grapes per person (2016), but the population consumes within $3 \mathrm{~kg}$, which is $40 \%$ to scientifically grounded consumption rates (6-8 $\mathrm{kg}$ ). The level of consumption of table grapes by half is ensured by import, which in 2012-2014 was 54-63.1 thousand tons, and in 2015 it decreased to 39.3 thousand tons. 
Table 5

Processing of grapes on wine materials by grade*

\begin{tabular}{|l|c|c|c|c|c|c|c|}
\hline \multirow{2}{*}{ Name of grape varieties } & \multicolumn{7}{|c|}{ YEARS } \\
\cline { 2 - 8 } & 2010 & 2011 & 2012 & 2013 & 2014 & 2015 & 2016 \\
\hline Aligote & 48470 & 44496,3 & 47493,2 & 57787,1 & 29877,2 & 23902,3 & 21853,4 \\
\hline Bastardo Magaratsky & 6183,8 & 10214,5 & 8100,4 & 6883,2 & 3470,5 & 5239,7 & 5818,1 \\
\hline Cabernet Sauvignon & 26315,4 & 35160,9 & 37092,2 & 36858 & 21288,7 & 17883,3 & 35464,2 \\
\hline Merlo & 8444,3 & 13578,9 & 8895,3 & 11703,2 & 10690,8 & 6153,5 & 13563,7 \\
\hline Muscat (white, pink, etc.) & 24229,8 & 29582,8 & 26076 & 31845,5 & 17756,2 & 11417,1 & 17121,6 \\
\hline Odessa black & 8163,6 & 7437,1 & 5119,6 & 6549,2 & 5100,4 & 3546,6 & 5213,7 \\
\hline Pino (white, black, gray) & 9414,9 & 11560,3 & 9074,6 & 14478,2 & 8027,4 & 7040,7 & 13529,7 \\
\hline Riesling & 14952,8 & 14478,4 & 13281,2 & 23363,7 & 13064,1 & 11621,0 & 11176,2 \\
\hline Rkatsiteli & 45021,5 & 46604 & 30830,1 & 37171,6 & 12648,7 & 9934,9 & 11547,2 \\
\hline Northern Saperavi & 10523,6 & 8160,4 & 7310 & 7522,1 & 5460,5 & 5376,7 & 10518,1 \\
\hline Sauvignon & 17736,9 & 22092,1 & 18186,7 & 22534 & 15725,0 & 10416,0 & 10529,1 \\
\hline Sukholimansky & 9012,6 & 4266,2 & 3259,9 & 3127,4 & - & - & 3353,3 \\
\hline Fetaska & 5537,1 & 3574,2 & 4778,2 & 6637,8 & 3063,6 & 2062,2 & 3023,9 \\
\hline Chardonnay & 20402,7 & 20774,9 & 30683 & 50898,8 & 24770,7 & 20277,5 & 28287,8 \\
\hline Traminer pink & - & - & - & - & - & 3276,0 & 3738,1 \\
\hline Others & 163280 & 81919,8 & 79449,3 & 108004,4 & 57989,3 & 55881,1 & 59118,2 \\
\hline
\end{tabular}

* compiled by the authors on the basis of the sources [5]

The largest export of table grapes was in 2013 and made 140 tons, that is, $0.02 \%$ of the total gross tax, and in 2014 - decreased to 6 tons. At the same time, the price of exported grapes is 2-3 times higher than the domestic one: in 2014 it amounted to 12.1 thousand $\mathrm{UAH}$ per ton against 4,0 thousand $\mathrm{UAH}$, which indicates a significant export attractiveness. [10].

Compared to 2013, the wine industry has reduced its profits by 3.3 times, indicating that there are significant problems in vine growing and winemaking. However, with the reduction of the import of grape wine to Ukraine (from 50.8 thousand tons in 2013 to 40.1 thousand tons in 2014), domestic winemakers will have more favorable conditions for the sale of their own products, to replace the lost volumes of supplies to the Russian Federation (1.6 times against 2013).

The development of viticulture and winemaking in the near future will be determined by the general economic situation in the state and the ability of the industry to respond promptly to the urgent challenges of the present. First of all, this concerns the reduction of gross grape harvest in 2016. On the other hand, the industry has practically lost significant amounts of state support through the abandonment of fees for the development of viticulture, horticulture and hop-growing (in 2010 almost 413 million UAH was paid in support of these industries, and in 2014 the least - 43,9 million UAH). The Government's decision on a special regime for the value-added tax on agricultural producers since January 2016 could lead to a significant reduction in the costs for the development of viticulture, reduced yields, and even reduction of their areas.

The greatest threat to the industry is negative macroeconomic trends, especially the decrease in the volume of solvent demand of the population. Both grapes and wine are not related to essential food, therefore it is likely that citizens can reduce the consumption of winemaking products.
Among other challenges, further reduction of exports of wine products to Russia will have a negative impact because of the military conflict and the growth of tension in the relationship. The Russian market consumed $84.3 \%$ of the total export of grape wine from Ukraine in 2014 , in 2013 it reached $89.4 \%$, and its loss is a serious challenge for the industry.

In addition, Ukrainian winegrowers and winemakers also have to prove the competitiveness of their products in the context of the EU-Ukraine Association establishment, the growth of competition on the world market, the continuation of economy globalization, etc. This requires new technologies, high-yielding varieties, productivity and product quality, increase diversification of production and sales markets, innovation development, creation and promotion of new brands of domestic winemaking products to foreign markets and much more, and without it is impossible to develop the industry successfully.

Traditionally, the production of wine remains a rather cost-effective and attractive industry for business. The dynamics of the grape wines production in the world over the past 50 years has generally been quite stable. In 2016 the world's production of wines increased by $6.4 \%$, while wine consumption by $0.06 \%$. Production of wine in Ukraine for the same period decreased by $11.1 \%$, and consumption decreased by $18.10 \%$. We can conclude that world wine production and consumption is stable, but in Ukraine production and consumption of wine is decreasing [11].

In recent years, the wine industry has been in a difficult economic situation. The wines production in Ukraine is falling dramatically, namely in 2014 production decreased by $43 \%$ in relation to 2013 , in 2015 - by $24 \%$ till 2014 , and in 2016 - by $8.6 \%$ till 2015 . During four years, because of the rapid drop in production, the total production of wine has reached its absolute minimum in recent years. 
Growth in prices for grapes is ahead of rising prices for winemaking products. This is due to a lack of highquality raw materials, outdated fleet of machinery and process equipment, but researchers see the main reason in the absence of solvent demand of the population in its low purchasing power.

Conclusions and prospects of the further investigations. Basing on the analysis, it can be concluded that to date there is an urgent need to develop and implement measures concerning the problems that hinder the development of viticulture. Among the priority areas of development of the industry are the following:

- taking measures to expand the area of vineyards;

- raising the level of care for vineyards;

- reduction of the viability of the vineyards;

- optimization of the structure of plantations (increase of the share of high-quality varieties for the production of champagne wines);

- application of progressive techniques of agrotechnics that will ensure the efficiency of grape production;

- legislative regulation of land relations, development of legal registration of the right to lease land under vineyards;

- attraction of additional investments on increase of areas of grape plantations.

Taking into account all existing problems in wine growing and winemaking, the Ministry of Agrarian Policy and Food of Ukraine and the Ukrainian Academy of Agrarian Sciences, by the general order dated July 21, 2008, №444/74, approved the sectoral Program for the Development of Horticulture of Ukraine for the period until 2025 and the sectoral Program for the Development of Viticulture and Wine of Ukraine until the year 2025. The purpose of creating the Program for the development of viticulture and winemaking till 2025 is the implementation of the state policy of Ukraine regarding the regulation of the development of this industry in the field of economy, the concentration of financial, logistical, other resources, production and scientific and technical potential. The main tasks for solving the problems of the industry in accordance with the program are the following [12]:

1) measures to increase the capacity of the market of grapes and products of its processing, taking into account the needs of the population, its purchasing power and the maximum export possibilities;

2) extension of the term of the Law of Ukraine "On the fee for the development of viticulture, horticulture and hop-growing" until 2025;

3 ) the gradual reduction of the import of wine materials and the pouring of wine simultaneously with the development of the domestic raw material base on the basis of the introduction of innovative and intensive technologies of grape production, which ensure its efficiency by increasing the yield of grape plantations and improving the quality of products;

4) improvement of the mechanism of providing state support to viticulture and ensuring the development of winemaking, taking into account the requirements of the WTO;

5) implementation of measures to ensure the development of the market infrastructure for wine products, diversification of sales channels and ensuring product quality, regulation of supply and demand, protection of the market from imported wine products and raw materials of low quality;

6) innovation and investment strengthening of the material and technical base of the grape-and-winemaking industry, introduction of environmentally safe, resource-saving and energy-saving technologies;

7) improvement of insurance and tax policy in the field of grape and wine production;

8) increasing of the role of science and education in accelerating of innovation processes in the winemaking industry;

9) preservation of labor resources, formation of an effective system of providing the field with personnel by training specialists on the target and attracting young specialists for work in vine growing and winemaking;

10) improvement of the system of management of innovative development in the grapes and winemaking industry;

11) development of sectorial normative and technological documentation, which complies with the provisions and requirements of the European Community at the expense of the funds provided for scientific research.

In general, to solve the urgent problems of innovative development of the wine industry, the activation of the wine market, the creation of innovative winemaking products it is necessary:

- to improve the quality of domestic wines and to establish restrictions on the import of raw materials;

- to take measures to detect and eliminate counterfeit products from the wine market;

- to increase the volume of investments in the innovative updating of the material and technical base of the winemaking industry;

- to develop a number of effective measures to increase the competitiveness of Ukrainian brands of innovative wine products on the world market;

- to increase the culture of wine consumption in Ukraine.

The last point, which is aimed at forming the culture of wine consumption, is realized with the use of marketing measures (through the establishment of wine culture centers, opening of specialized wine shops, development of wine tourism, organization of exhibitions, tasting).

We can conclude that the world's production and consumption of wine has a stable demand, but in Ukraine, not only wine production and consumption, but also the area of grapevines decreases. Domestic viticulture has significantly reduced production volumes under the influence of recent political processes. Its development is increasingly dependent on macroeconomic processes and state policy to support the industry, as well as on the peculiarities of the household sector, which produces more than $40 \%$ of production. 


\title{
References
}

1. TOP National Brands. (2015). Retrieved from http://www.ukrbrand.com.ua/

2. Man Tanga, V. C., Tchetchik, A., \& Cohenc, E. (2015, March 11). Perception of wine labels by Hong Kong Chinese consumers. http://dx.doi.org/10.1016/j.wep.2015.02.002

3. Osypov, V. (2015, September 18). Vynohradarstvo ta vynorobstvo Ukrainy. Suchasnyi stan, problemy, tendentsii rozvytku. Retrieved from http://ua-ekonomist.com/10132-vinogradarstvo-ta-vinorobstvo-ukrayini-suchasniystan-problemi-tendencyi-rozvitku.html

4. Deiaki pytannia vyznachennia serednostrokovykh priorytetnykh napriamiv innovatsiinoi diialnosti zahalnoderzhavnoho rivnia na 2012-2016 rr. (2015). Retrieved from http://zakon5.rada.gov.ua/laws/show/294-2012-\%D0\%BF

5. Derzhavna sluzhba statystyky Ukrainy. (2017). Retrieved from http://www.ukrstat.gov.ua

6. Kucherenko, V. M. (2014). Dynamika rozvytku vynohradarstva i vynorobstva v Ukraini. Efektyvna ekonomika, (12), 46-52.

7. Ministerstvo ekonomichnoho rozvytku i torhivli Ukrainy. (2017). Retrieved from http://www.me.gov.ua

8. Nesterenko, O. S. (2015). Tendentsii ta perspektyvy rozvytku vynorobnoi haluzi v Ukraini. Retrieved from http://molodyvcheny.in.ua/files/journal/2015/2/104.pdf

9. Matviienko, M. I. Mistse upakovky v systemi marketynhovykh komunikatsii. Retrieved from http://bukvar.su/marketing/page,2,137707-Mesto-upakovki-v-sisteme-marketingovyh-kommunikaciiy.html

10. Ekspres-vypusk Derzhavna sluzhba statystyky Ukrainy 14.01.2015r. №2/0/06.2vn-15 Pererobka vynohradu ta vyrobnytstvo vynomaterialiv u 2014 r. (2015, January 14). Retrieved from http://ukrstat.org.ua

11. Zakon Ukrainy «Pro osnovni zasady derzhavnoho nahliadu (kontroliu) u sferi hospodarskoi diialnosti» vid 26.12.2007 roku: za stanom na 1 sichnia 2017 r. (2017). Retrieved from http://www.zakon.rada.gov.ua

Received 03 October 2017

Approved 17 October 2017

Available in Internet 30.12.2017

\author{
Каламан О.Б. \\ кандидат экономических наук, доцент \\ E-mail: kalaman.olga@gmail.com \\ Зборщик Д.П. \\ магистрант \\ кафедра менеджмента и логистики \\ Одесская национальная академия пищевых технологий \\ ул. Канатная, 112, г. Одесса, Украина, 65039 \\ E-mail: dasha.zborshik@mail.ru
}

\section{АНАЛИЗ ПРОБЛЕМ ВИНОГРАДАРСТВА И ВИНОДЕЛИЯ УКРАИНЫ И УПРАВЛЕНИЕ МЕХАНИЗМОМ РАЗВИТИЯ ОТРАСЛИ}

В статье показано современное состояние и основные проблемы отрасли виноградарства и виноделия в Украине и мире. Представлена структура площадей виноградных насаждений в мире и агроклиматические условия, которые на них влияют. Уточнено, с какого периода начались разрушительные процессы в этой сфрере на юге Украины и по каким именно причинам отсутствует процесс восстановления отрасли.

Подчеркнуты основные факторы, влияющие на урожайность винограда, и причины сложности инвестирования отрасли. Это обусловлено временным лагом между вложением средств и первым урожаем с новых кустов. Показано, что именно красные вина пользуются спросом в Украине, однако предприятия должны также учитывать спрос на готовую продукцию винодельческой отрасли в странах EC, если планируют выходить на эти рынки.

Проведенный анализ основных показателей развития отрасли по годам и показаны основные негативные тенденции отрасли: старение насаждений, сокращение площадей, недостаточное внимание именно к виноградарству со стороны предприятий-переработчиков и другие. При анализе сопоставлено объемы переработанного винограда на виноматериал по всем регионам, собственно выращенного и закупленного. Это подтверждает недостаточное количество собственно выращенного качественного винограда для переработки винодельческими предприятиями. Однако сегодня обострился вопрос отсутствия связи между фермерскими хозяйствами, занимающимися выращиванием винограда, и большими винодельческими предприятиями полного цикла.

Особого внимания заслуживает сортовой состав винограда, выращиваемого на территории Украины. Анализ его позволяет сделать выводы, что винодельческие предприятия могут занимать 
лидирующие позиции на европейском рынке. Также в статье показано, что наибольшую угрозу для отрасли составляют негативные макроэкономические тенденции, особенно уменьшение объемов платежеспособного спроса населения. И виноград, и вино, не относятся к продуктам первой необходимости, поэтому вполне вероятно, что граждане могут уменьшить потребление винодельческой продукции. Сделанные выводы о существующей необходимости в разработке и внедрении мероприятий для решения проблем, которые сдерживают развитие виноградарства Украины на сегодня.

Ключевые слова: валовой сбор винограда, площади виноградных насаждений, переработка винограда, производство вина, винодельческие предприятия.

\author{
Каламан О.Б. \\ кандидат економічних наук, доцент \\ E-mail: kalaman.olga@gmail.com \\ Зборщик Д.П. \\ магістрант \\ кафедра менеджменту і логістики \\ Одеська національна академія харчових технологій \\ вул. Канатна, 112, м. Одеса, Україна, 65039 \\ E-mail: dasha.zborshik@mail.ru
}

\title{
АНАЛІЗ ПРОБЛЕМ ВИНОГРАДАРСТВА І ВИНОРОБСТВА УКРАЇНИ ТА УПРАВЛІННЯ МЕХАНІЗМОМ РОЗВИТКУ ГАЛУЗІ
}

В статті показаний сучасний стан та основні проблеми галузі виноградарства та виноробства в Україні та світі. Представлено структуру площ виноградних насаджень в світі та агрокліматичні умови, що на них впливають. Уточнено, з якого періоду почались руйнівні процеси в цій сфері на півдні України і з яких саме причин відсутній процес відновлення галузі.

Підкреслено основні фрактори, які впливають на врожайність винограду, та причини складності інвестування галузі. Це обумовлено часовим лагом між вкладенням коштів та першим врожаєм 3 нових кущів. Показано, що саме червоні вина користуються попитом в Україні, проте підприємства мають також враховувати попит на готову продукцію виноробної галузі в країнах ЄС, якщо планують виходити на ці ринки.

Проведений аналіз основних показників розвитку галузі по роках та показано основні негативні тенденції галузі: старіння насаджень, скорочення площ, недостатня увага саме до виноградарства 3 боку підприємств-переробників та інші. Під час аналізу порівняно обсяги переробленого винограду на виноматеріал за регіонами всього, власновирощеного та закупленого. Це підтверджує недостатню кількість власновирощеного якісного винограду для переробки виноробними підприємствами. Проте на сьогодні загострилось питання відсутності зв'язку між фрермерськими господарствами, що займаються вирощуванням винограду, та великими виноробними підприємствами повного циклу.

На особливу увагу заслуговує сортовий склад винограду, що вирощується на території України. Аналіз його дозволяє зробити висновки, що виноробні підприємства можуть займати лідируючи позиції на європейському ринку. Також у статті показано, що найбільшу загрозу для галузі складають негативні макроекономічні тенденції, особливо зменшення обсягів платоспроможного попиту населення. І виноград, і вино, не відносяться до продуктів першої необхідності, тому цілком ймовірно, що громадяни можуть зменшити споживання виноробної продукції. Зроблені висновки про нагальну потребу у розробці та впровадженні заходів для розв'язання проблем, які стримують розвиток виноградарства України на сьогодні.

Ключові слова: валовий збір винограду, площі виноградних насаджень, переробка винограду, виробництво вина, виноробні підприємства.

\section{Література}

1. TOP National Brands [Електронний ресурс]. - Режим доступу: http://www.ukrbrand.com.ua/.

2. Vicky Chi ManTanga, Anat Tchetchik, Eli Cohenc. Perception of wine labels by Hong Kong Chinese consumers / Vicky Chi Man Tanga, Anat Tchetchik, Eli Cohenc // [Електронний ресурс]. - Режим доступу: http://dx.doi.org/10.1016/j.wep.2015.02.002

3. Осипов В. Виноградарство та виноробство України. Сучасний стан, проблеми, тенденції розвитку [Електронний ресурс]. - Режим доступу: http://ua-ekonomist.com/10132-vinogradarstvo-ta-vinorobstvo-ukrayinisuchasniy-stan-problemi-tendencyi-rozvitku.html 
4. Деякі питання визначення середньострокових пріоритетних напрямів інноваційної діяльності загальнодержавного рівня на 2012-2016 рр. / Постанова КМУ [Електронний ресурс]. - Режим доступу: http://zakon5.rada.gov.ua/laws/show/294-2012-\%D0\%BF

5. Державна служба статистики України [Електронний ресурс]. - Режим доступу: http://www.ukrstat.gov.ua

6. Кучеренко В.М. Динаміка розвитку виноградарства і виноробства в Україні / В.М. Кучеренко // Ефективна економіка. - 2014. - №12. - С. 46-52.

7. Міністерство економічного розвитку і торгівлі України [Електронний ресурс]. - Режим доступу http://www.me.gov.ua

8. Нестеренко О.С. Тенденції та перспективи розвитку виноробної галузі в Україні. [Електронний ресурс]. - Режим доступу: http://molodyvcheny.in.ua/files/journal/2015/2/104.pdf

9. Матвієнко М.І. Місце упаковки в системі маркетингових комунікацій [Електронний ресурс] - Режим доступу: http://bukvar.su/marketing/page,2,137707-Mesto-upakovki-v-sisteme-marketingovyhkommunikaciiy.html

10. Експрес-випуск Державна служба статистики України 14.01.2015p. №2/0/06.2вн-15 Переробка винограду та виробництво виноматеріалів у 2014 р. [Електронний ресурс]. - Режим доступу: http://ukrstat.org.ua

11. TOP National Brands [Електронний ресурс]. - Режим доступу: http://www.ukrbrand.com.ua/

12. Закон України «Про основні засади державного нагляду (контролю) у сфері господарської діяльності» від 26.12.2007 року : за станом на 1 січня 2017 р. [Електронний ресурс]. - Режим доступу: http://www.zakon.rada.gov.ua

Стаття надійшла 03.10.2017

Стаття прийнята до друку 17.10.2017

Доступно в мережі Internet 30.12.2017 